\title{
DETERMINATION OF ANTIOXIDANT CAPACITY, FLAVONOIDS, AND TOTAL PHENOLIC CONTENT IN EUCALYPTUS AND CLOVER HONEYS
}

\author{
María C. Ciappini \\ Fernando S. Stoppani \\ CIDTA - Universidad Tehnológica Nacional - Facultad Regional Rosario \\ - E. Zeballos 1341 - S2000BUN Rosario - Argentina. \\ *corresponding author: mcciappini@frro.utn.edu.ar \\ Received 25 July 2013; accepted 24 February 2014
}

\begin{abstract}
Polyphenolic compounds reportedly produce physiological effects that are beneficial to health. Bee products are particularly rich in polyphenolic compounds. We determined the antioxidant capacity and the phenolic and flavonoid compounds content of 81 samples of honey. We used the Folin-Ciocalteu reagent method to evaluate the total phenolic content. The antioxidant activities were evaluated using in vitro scavenging assays of 2,2-diphenyl-1-picrylhydrazyl (DPPH) and hydroxyl radicals (OH), Trolox equivalent antioxidant capacity (TEAC), and ferric-reducing antioxidant capacity (FRAC). Total phenolic content ranged from 40.3 to $193.0 \mathrm{mg}$ gallic acid equivalents (GAE)/100 g; the flavonoid content varied from 1.4 to $7.5 \mathrm{mg}$ quercetin equivalents (QE)/100 g. Eucalyptus honeys exhibited significantly higher phenolic content and free radical-scavenging activity than clover honey samples ( $p<0.05$ for all). Principal component analysis explained $73 \%$ of the differences observed in antiradical activity with respect to floral origin. Total phenolic content may be more useful than the radical-scavenging assay for detecting antioxidant capacity in honey; it also represents the variable that most appropriately discriminated among these honeys.
\end{abstract}

Keywords: DPPH, ferric-reducing antioxidant capacity, flavonoids in honey, hydroxyl radicals, polyphenols, Trolox equivalent antioxidant capacity.

\section{INTRODUCTION}

Recently, there has been an increasing interest in the antioxidant capacity of food. Nutritive antioxidant capacity plays an important role as a health-protecting factor. Extracts with antioxidant properties are already being sold as food ingredients, and are also widely used as additives in food processing to prevent or delay spoilage of food (Blasa et al., 2007). In vegetables, this capacity is attributed to the presence of phenolic compounds, mainly flavonoids. It is agreed that the antioxidant activity of flavonoids results from a combination of iron-chelating properties and free-radical capture (Bertonceij et al., 2007), while phenolic acids work as antioxidants by employing free radical-scavenging mechanisms (Hamdy et al., 2009). Others also mention enzymatic oxidation inhibition (enacted by lipoxygenase, ciclooxigenase, myeloperoxidase, and xanthine oxidase), which avoids the in vivo generation of reactive oxygen species (ROS) and organic hydroperoxides (Aljadi and Kamaruddin, 2004; Baltrušaitytè et al., 2007).

Bee products are especially rich in these bioactive compounds. Honeys have a rich phenolic profile consisting of benzoic acid and its esters, cinnamic acid and its esters, and flavonoid aglycones (Hamdy et al., 2009). They can also contain a wide variety of nitrogen compounds (alkaloids, chlorophyll derivates, amino acids and amines), carotenoids, and vitamin $\mathrm{C}$, whose antioxidant activities are widely recognized (Buratti et al., 2007; Pérez et al., 2007). However, the antioxidant activity of honey varies greatly depending on its floral source (Liviu et al., 2011).

Honeys differ not only with respect to chemical composition (volatile compounds, carbohydrates, and phytochemicals), physical properties (color, viscosity, hygroscopic properties, and $\mathrm{pH}$ ) and taste, but also with respect to biological activity. Some honeys have a stronger biological activity than others. Con- 
sequently, it is a reasonable expectation that the composition and properties of honeys from various locations might differ (Kaškonienė et al., 2009).

Many methods have been used to determine honey's antioxidative activity, including: the determination of flavonoids and total phenolic content (Beretta et al., 2005); radical formation and radical scavenging, as in 2,2-diphenyl-1-picrylhydrazyl (DPPH), and the measurement of superoxide radical-scavenging activity (Gheldof et al., 2002; Aljadi and Kamaruddin, 2004; Meda et al., 2005); the ferric-reducing antioxidant power assay (Aljadi and Kamaruddin, 2004); oxygen radical absorbance capacity (ORAC), Trolox equivalent antioxidative activity (TEAC); and enzymatic or non-enzymatic measurements of lipid peroxidation inhibition (McKibben and Engeseth, 2002). In most cases, it is necessary to use several tests to obtain good reliability (Roginsky and Lissi, 2005).

Recently developed biological methods are more relevant than the popular in vitro assays, because they take into account some aspects of the metabolism, intake, and location of antioxidant compounds in cells. However, these methods have been questioned because no correlation has been observed between their results and biological activities (Blasa et al., 2007).

The aim of this work was to measure the antioxidant capacity, total phenolic compound content, and flavonoid content in eucalyptus and clover honeys, in order to estimate the nutritional relevance of antioxidant capacity, which also contributes to the characterization of these honeys.

\section{MATERIAL AND METHODS}

\section{Samples}

Eighty-one honey samples collected between 2006 and 2010 were analyzed. In every case, samples were collected in accordance with CODEX Stan 12 (2001), in the Argentinean phytogeographical region known as the Pampeana Region. This region is characterized by grass pasture but has been highly altered by the development of many crops (Triticum aestivum L., Zea mays L., Glycine max (L.) Merr., Oryza sativa) and animal feed harvests (Lotus sp., Medicago sativa L., Trifolium repens L., Trifolium pratense L., Melilotus albus), with predominance of non-native species and poor pollen diversity. As the Pampeana Region is mainly committed to agriculture and ranching, crops and their weeds have largely replaced native vegetation, creating an important resource for honey production in the region (Fagúndez and Caccavari, 2006).

According to a palynological analysis (Loveaux et al., 1978), 53 honeys were from clovers (Trifolium sp.) and 28 were from eucalyptus (Eucalyptus sp.). Upon receipt, honey samples were centrifuged and stored at $-18^{\circ} \mathrm{C}$ in the dark until analysis. Sample analysis was performed within 4 months of sample harvest.

\section{Quantification of bioactive compounds} Total soluble phenolic compound content

In order to measure the total soluble phenol content of honey samples, we employed phenolic compounds to reduce a phosphowolframate-phosphomolybdate complex to blue products (Singleton et al., 1999). Each honey sample $(4.0 \pm 0.01 \mathrm{~g})$ was diluted to $25 \mathrm{~mL}$ with distilled water and filtered through Whatman $\mathrm{N}^{\circ} 1$ paper. Ten milliliters of distilled water were added to $1 \mathrm{~mL}$ of this solution and mixed with $1 \mathrm{~mL}$ of Folin-Ciocalteu reagent, shaking gently. After $2 \mathrm{~min}, 2 \mathrm{~mL}$ of saturated sodium carbonate solution were added to the mixture and adjusted to $25 \mathrm{~mL}$ with distilled water. After incubation in the dark at room temperature for $2 \mathrm{~h}$, the absorbance of the resulting solution was measured at $725 \mathrm{~nm}$ in a Varian Cary 50 spectrophotometer (Las Vegas, USA). Gallic acid was used as standard for the calibration curve $(0.01-2.90 \mathrm{mM} ; \mathrm{Y}=42.40 \mathrm{X}+0.21$; $\left.\mathrm{R}^{2}=0.998\right)$. The mean of two readings was used and expressed as milligrams of gallic acid equivalents (GAE) per $100 \mathrm{~g}$ honey.

\section{Flavonoid compound content}

In order to determine flavonoid content, to each honey sample $(2.5 \pm 0.01 \mathrm{~g})$ we added $0.5 \mathrm{~mL}$ of $\mathrm{AlCl}_{3} 5 \%$, and then brought the total volume to $25 \mathrm{~mL}$ with distilled water. Diluted samples were incubated for $30 \mathrm{~min}$ in the dark at room temperature, after which absorption readings were obtained at $425 \mathrm{~nm}$ (Woisky and Salatino, 1998). The total flavonoid content was determined using a standard curve, with quercetin as the standard $(0.00$ $\left.28.70 \mathrm{mM} ; \mathrm{Y}=15.33 \mathrm{X}-0.189 ; \mathrm{R}^{2}=0.997\right)$. The mean of two readings was used and expressed as milligrams of quercetin equivalents (QE) per $100 \mathrm{~g}$ honey.

\section{Antioxidant capacity}

The antioxidant capacity of different honey samples was evaluated using the whole sample. Spectrophotometric assays were performed using a Varian Cary 50 spectrophometer (Las Vegas, NV, USA).

\section{DPPH radical-scavenging activity}

We used the method suggested by Brand-Williams et al. (1995) to assess DPPH radical-scavenging activity. Each honey sample $(0.7 \pm 0.01 \mathrm{~g})$ was diluted in $50 \mathrm{~mL}$ of water. Two milliliters of this 
solution were mixed with $2 \mathrm{~mL} 0.1 \mathrm{M} \mathrm{DPPH}$ ethanol solution (freshly prepared). The mixture was shaken vigorously and left to stand for 60 min in the dark, after which stable absorption values were obtained. The reduction of the DPPH radical was determined by measuring the absorption at $515 \mathrm{~nm}$; absorbance was read after adjustment at 1 with DPPH solution. Results were expressed as milligrams of Trolox equivalents (TE) per $100 \mathrm{~g}$ honey, using the standard calibration curve $(0.00-63.40 \mathrm{mM} ; \mathrm{Y}=41.91 \mathrm{X}$ 0.13; $R^{2}=0.999$ ).

\section{Trolox equivalent antioxidative capacity (TEAC) or ABTS assay}

The ABTS assay was performed according to Arnao et al. (2001). The ABTS radical (ABTS"+) was obtained by reacting 2,2'-azino-bis-3-ethylbenzthiazoline-6sulphonic acid (ABTS) $7 \mathrm{mM}$ solution with $2.45 \mathrm{mM}$ potassium persulfate. The solution was stored in the dark at room temperature between 12 - $16 \mathrm{~h}$, and then diluted in ethanol to read absorbance of $0.70 \pm 0.02$ at $734 \mathrm{~nm}$. Four milliliters of ABTS solution were mixed with $0.1 \mathrm{~mL}$ of $10 \%$ honey aqueous solution. This mixture was kept in the dark for $24 \mathrm{~h}$. Absorbance was read at $734 \mathrm{~nm}$ against ethanol; absorbance was adjusted at 0.7 with ABTS solution. Results were expressed as milligrams of Trolox equivalents (TE) per $100 \mathrm{~g}$ honey, based on the standard calibration curve $(0.00-0.50 \mathrm{mM}$; $\left.Y=-364.86 X+241.95 ; R^{2}=0.973\right)$.

\section{Ferric-reducing antioxidant capacity (FRAC)}

The reducing capacity of a compound can reflect its antioxidant capacity (Oyaizu, 1986). Two milliliters of $0.03 \mathrm{~g} / \mathrm{mL}$ honey aqueous solution were mixed with $2 \mathrm{~mL}$ sodium phosphate buffer solution (0.2 M, pH = 6.6) and $2 \mathrm{~mL} 1 \%$ potassium ferricyanide $\left(\mathrm{K}_{3}[\mathrm{Fe}(\mathrm{CN})]_{6}\right)$. The homogenized mixture was incubated at $50^{\circ} \mathrm{C}$ for $20 \mathrm{~min}$. Then, $2 \mathrm{~mL}$ of trichloroacetic acid were added. Five milliliters of distilled water and $1 \mathrm{~mL}$ ferric chloride $1 \%\left(\mathrm{FeCl}_{3}\right)$ were added to $5 \mathrm{~mL}$ of the homogenized mixture. The absorbance was read at $700 \mathrm{~nm}$. Reductive capacity was expressed according to the calibration curve (0.00 - $\left.113.56 \mathrm{mM} ; Y=67.06 \mathrm{X}-215.90 ; R^{2}=0.993\right)$ using ascorbic acid as the standard. The results were expressed as milligrams of ascorbic acid equivalent (AAE) per $100 \mathrm{~g}$ honey.

\section{OH radical-scavenging activity}

$\mathrm{OH}$ radical-scavenging activity was measured by assessing the inhibitory capacity of the degradation of desoxyribose (Halliwel et al., 1987). In the presence of ascorbic acid, $\mathrm{H}_{2} \mathrm{O}_{2}$-ferric-EDTA complex produces the Fenton reaction. Free radicals attack desoxyribose, degrading it into fragments that react with thiobarbituric acid to yield a pink chromogen. The color of the solution changes when honey competes for the $\mathrm{OH}$.

This assay was performed by first mixing $0.1 \mathrm{~mL}$ desoxirribose solution (28 mM) with $200 \mu \mathrm{L}$ of $0.02 \mathrm{~g} / \mathrm{mL}$ honey aqueous solution Next, $0.5 \mathrm{~mL}$ phosphate buffer $(40 \mathrm{mM}, \mathrm{pH}=7.4), 0.1 \mathrm{~mL}$ ferric chloride (1 mM), $0.1 \mathrm{~mL}$ EDTA $(1.04 \mathrm{mM}), 0.1 \mathrm{~mL}$ $\mathrm{H}_{2} \mathrm{O}_{2}(1 \mathrm{mM})$, and $0.1 \mathrm{~mL}$-ascorbic acid $(1 \mathrm{mM})$ were added. After incubation at $37^{\circ} \mathrm{C}$ for $1 \mathrm{~h}$ in a thermostatic bath, $0.5 \mathrm{~mL}$ thiobarbituric acid (1\% P/V in $0.05 \mathrm{M} \mathrm{NaOH}$ ) and $0.5 \mathrm{~mL} \mathrm{2.8 \%} \mathrm{(v/v)} \mathrm{trichloriacetic}$ acid were added. This mixture was left to react for $10 \mathrm{~min}$ at $100^{\circ} \mathrm{C}$, and absorbance was measured at $530 \mathrm{~nm}$. Quercetine was used as a reference substance (QE), and the corresponding concentration was calculated using a calibration curve $(0.00$ $\left.113.56 \mathrm{mM} ; \mathrm{Y}=-0.001 \mathrm{X}+0.0005 ; \mathrm{R}^{2}=0.994\right)$.

\section{Statistical analysis}

The assays were performed in duplicate, and the results were expressed as mean values and standard deviation. Student's t-test was performed on the replicated samples. We considered $p<0.05$ statistically significant.

Principal component analysis (PCA) was conducted to characterize each floral origin with respect to antioxidant activity. PCA is a multivariate statistical tool that indicates the relationship between a given group of variables from a data matrix and the similarity between individuals. The data matrix can be viewed as a multidimensional space with one dimension for each variable, and each sample as a point in that space. The matrix reduces by linear combinations of the original variables; the sample space is reduced, while retaining the highest proportion of the variance present in the original data (Johnson, 2004).

Descriptive and multivariate statistical analyses were performed using SAS ${ }^{\odot}$ v 9.3 (SAS Institute, 2011).

\section{RESULTS}

\section{Quantification of bioactive compounds}

Total phenolic content was between 40.30 and $193.03 \mathrm{mg}$ GAE per $100 \mathrm{~g}$ honey (mean $93.75 \pm$ $37.06 \mathrm{GAE} / 100 \mathrm{~g}, \mathrm{n}=81$ ). The flavonoid content in honey samples ranged from 1.42 to $7.48 \mathrm{mg}$ QE/100 g honey (mean $3.52 \pm 1.19 \mathrm{mg}$ QE/100 g, $n=81)$.

Fifty percent of eucalyptus honey samples exhibited a minimum total phenol level of 106.7 $\mathrm{mg}$ GAE/100 $\mathrm{g}$ and a minimum flavonoid level of 
$3.6 \mathrm{mg} \mathrm{QE/100} \mathrm{g.} \mathrm{In} \mathrm{contrast,} \mathrm{75 \%} \mathrm{of} \mathrm{clover} \mathrm{honey}$ samples exhibited a maximum total phenol level of $100.4 \mathrm{mg} \mathrm{GAE} / 100 \mathrm{~g}$ and a maximum flavonoid level of $3.9 \mathrm{mg} Q E / 100 \mathrm{~g}$. Clover honey samples contained significantly lower mean levels of phenolic compounds than eucalyptus honey samples (82.73 $\pm 28.04 \mathrm{mg}$ GAE/100g honey ( $n=53$ ) vs. 109.37 $\pm 41.44 \mathrm{mg}$ GAE/100 g honey ( $n=28) ; p \leq 0.05)$. Eucalyptus honey samples also contained significantly more flavonoid compounds than clover honeys $(p \leq 0.05)$. The average flavonoid compound content was equal to $4.03 \pm 1.22 \mathrm{mg} \mathrm{QE} / 100 \mathrm{~g}$ for eucalyptus honey and $3.29 \pm 1.10 \mathrm{mg} Q E / 100 \mathrm{~g}$ for clover honey samples.

\section{Antioxidant capacity}

The box plots in Figure 1 depict the differences in antioxidant activity between eucalyptus and clover honey. The TEAC of eucalyptus honey samples is significantly higher than that of clover honey samples $(p \leq 0.05)$.

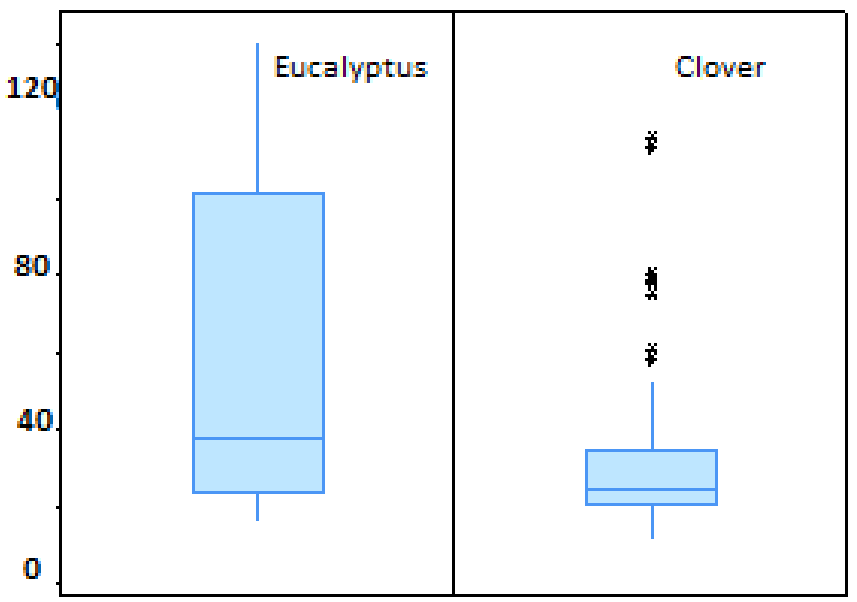

$\mathrm{DPPH}[\mathrm{mg} \mathrm{TE} / 100 \mathrm{~g}]$

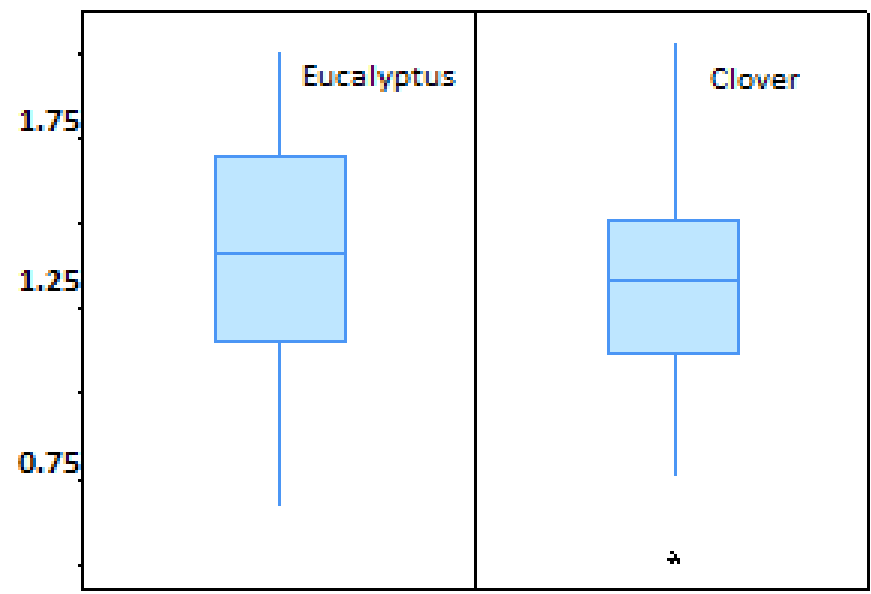

$\mathrm{OH}$ [mg QE/100 g]
The $\mathrm{OH}$ values ranged from 0.52 to $2.03 \mathrm{mg}$ $\mathrm{QE} / 100 \mathrm{~g}$ (mean $1.34 \pm 0.33 \mathrm{mg} Q \mathrm{E} / 100 \mathrm{~g}, \mathrm{n}=81$ ) and the FRAC values ranged from 2.50 to $98.10 \mathrm{mg}$ $A A E / 100 \mathrm{~g}$.

After the data matrix was standardized, we performed a PCA regarding several variables: total phenolic compound content, total flavonoid compound content, reducing capacity (FRAC), TEAC, and capture capability from DPPH radicals (DPPH) and $\mathrm{OH}$ radicals $(\mathrm{OH})$. Eigenvalues for the three first principal components (PCs) were: $\lambda 1=2.34$, $\lambda 2=1.19$, and $\lambda 3=0.78$. This finding explained $73 \%$ of total data variation, an acceptable criterion to represent the original information with only three new latent variables.

Figure 2 shows the correlation circle of the loading of the variables on the components. Each variable is a point whose coordinates are defined by the loading on the PCs (Tab. 1). The plot describes the correlation between the variables. Projecting the

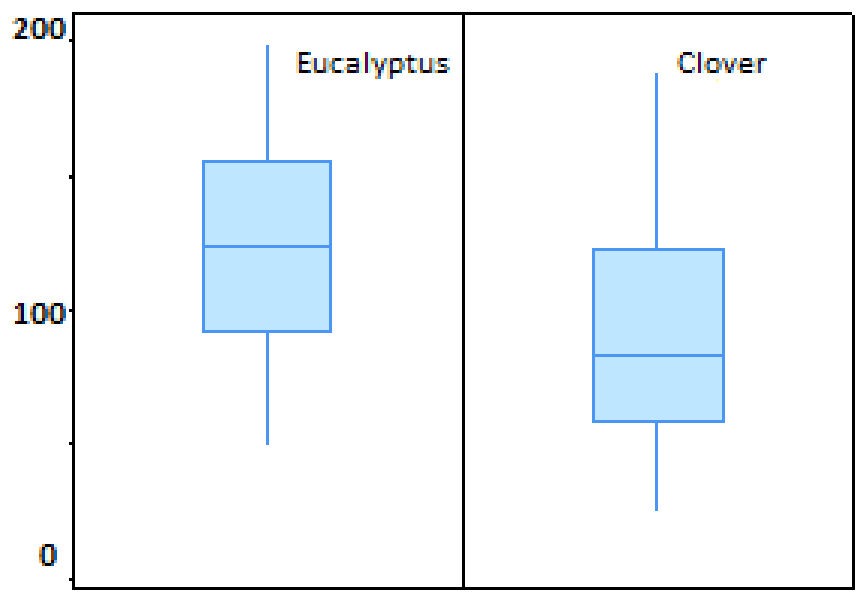

TEAC [mg ET/100 g]

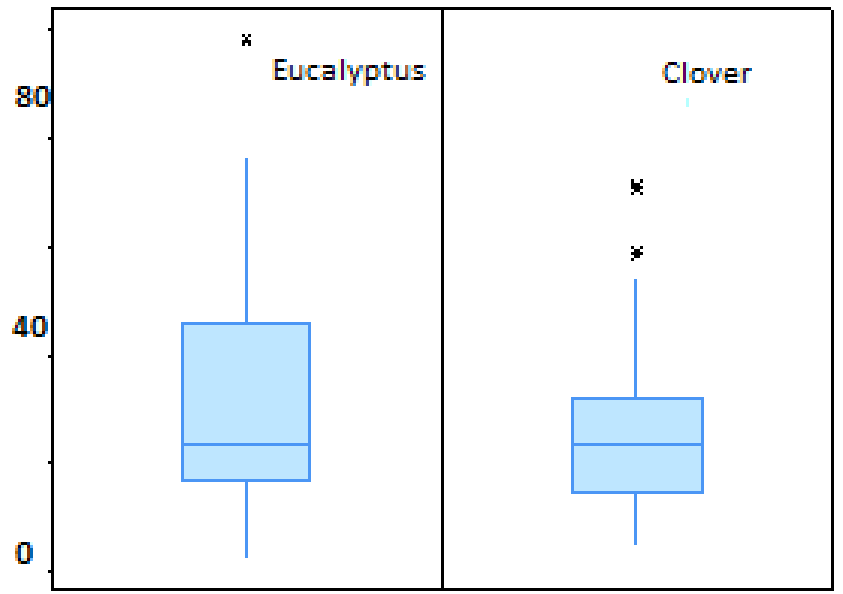

FRAC [mg AAE/100 g]

Fig. 1. Box and whisker plots show the minimum and maximum (vertical line), median (center horizontal line), first and third quartiles (box), and outliers (asterisk) of the antioxidant capacity of clover and eucalyptus honeys. 
Table 1.

Loading and cumulative variance for the three first principal components (PCs) of the principal content analysis regarding antioxidant capacity

\begin{tabular}{|c|c|c|c|c|c|c|c|}
\hline \multirow[b]{2}{*}{$P C$} & \multicolumn{6}{|c|}{ Variables } & \multirow{2}{*}{$\begin{array}{l}\text { Cumulative } \\
\text { variance } \%\end{array}$} \\
\hline & $\begin{array}{l}\text { Phenol } \\
\text { content }\end{array}$ & $\begin{array}{c}\text { Flavonoid } \\
\text { content }\end{array}$ & FRAC & DPPH & TEAC & $\mathrm{OH}$ & \\
\hline 1 & $0.52^{(*)}$ & 0.44 & 0.46 & 0.35 & 0.43 & $-0.92^{(*)}$ & 41 \\
\hline 2 & 0.08 & 0.32 & -0.35 & 0.29 & -0.11 & $0.82^{(*)}$ & 19 \\
\hline 3 & 0.05 & 0.22 & -0.00 & $-0.82^{(*)}$ & 0.45 & 0.26 & 73 \\
\hline
\end{tabular}

(*) Loadings involved in the differentiation of honey are highlighted in bold.

FRAC - ferric-reducing antioxidant capacity; DPPH - 2,2-diphenyl-1-picrylhydrazyl radical-scavenging activity;

TEAC - Trolox equivalent antioxidative capacity; $\mathrm{OH}$ - hydroxyl radical-scavenging activity

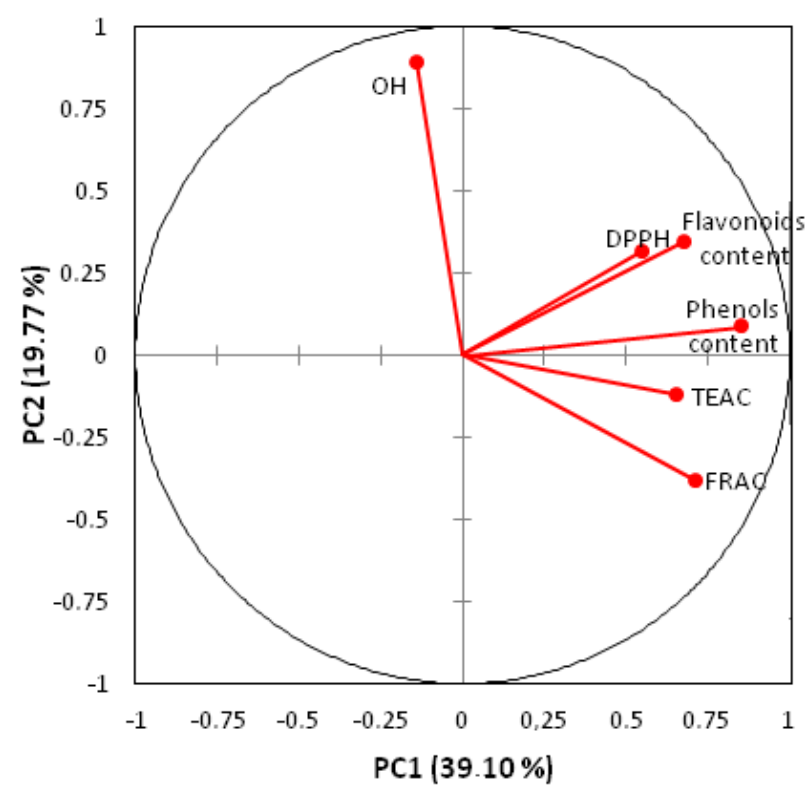

a

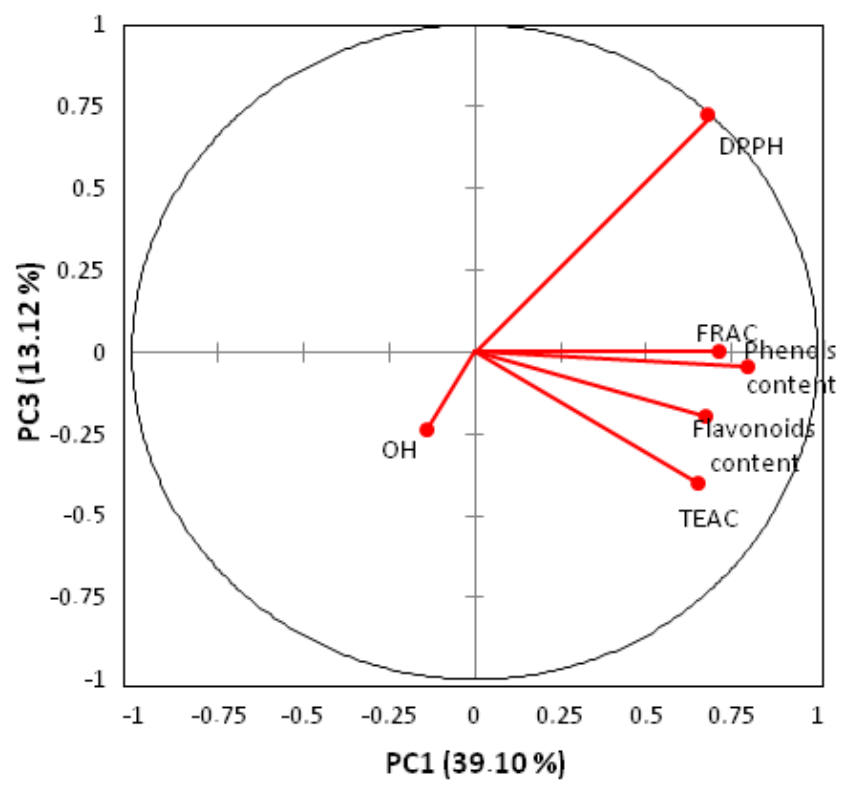

b

Fig. 2. Circle of correlations and plot of the loading of the variables (a) with principal components (PCs) 1 and 2, and (b) with PCs 1 and 3.

arrows onto the axis, it can be seen that phenol content is the most important variable for the first principal component (PC1), $\mathrm{OH}$ is the most important variable for the second principal component (PC2), and DPPH is the most important variable for the third principal component (PC3). The angle between two arrows represents the correlation of the respective variables. Smaller angles between vectors indicate an increased correlation between the respective variables. There is no linear dependence (i.e., no correlation) if the angle is 90 degrees. The $\mathrm{OH}$ radicalscavenging activity exhibited no correlation with the other antioxidant parameters assayed.

\section{DISCUSSION}

Figure 3 shows comparative results of total soluble phenolic compound content in honey samples from different sources. Meda et al. (2005) reported total phenolic contents between 32.59 and $114.75 \mathrm{mg}$ $\mathrm{GAE} / 100 \mathrm{~g}$ in multifloral honeys and honeydews. Vit et al. (2008) reported values between 47.4 and $265.49 \mathrm{mg}$ GAE/100 $\mathrm{g}$ in Czech honeys. Others observed narrower ranges (Gheldof et al., 2002; Otilia et al., 2005; Bertonceij et al., 2007; Sosa Martínez et al., 2009; González Lorente et al., 2008; Álvarez Suárez et al., 2009), with the exception of Muñoz et al. (2007), who reported values between 0.0 and $8.82 \mathrm{mg}$ GAE/100 g regarding Chilean honey. Comparative data of flavonoids content are shown in Figure 4. Medaetal.(2005)identified mean flavonoids content values of $2.57 \pm 2.09 \mathrm{mg}$ QE/100 $\mathrm{g}$ in multifloral honeys and honeydews. Values reported by Vit et al. (2008) ranged from 1.90 to $15.74 \mathrm{mg}$ QE/100 g for Czech honeys. Others authors reported smaller ranges (Baltrušaitytè et al., 2007; Muñoz et al., 2007; Álvarez Suárez et al., 2009; Sosa Martínez et al., 2009). 


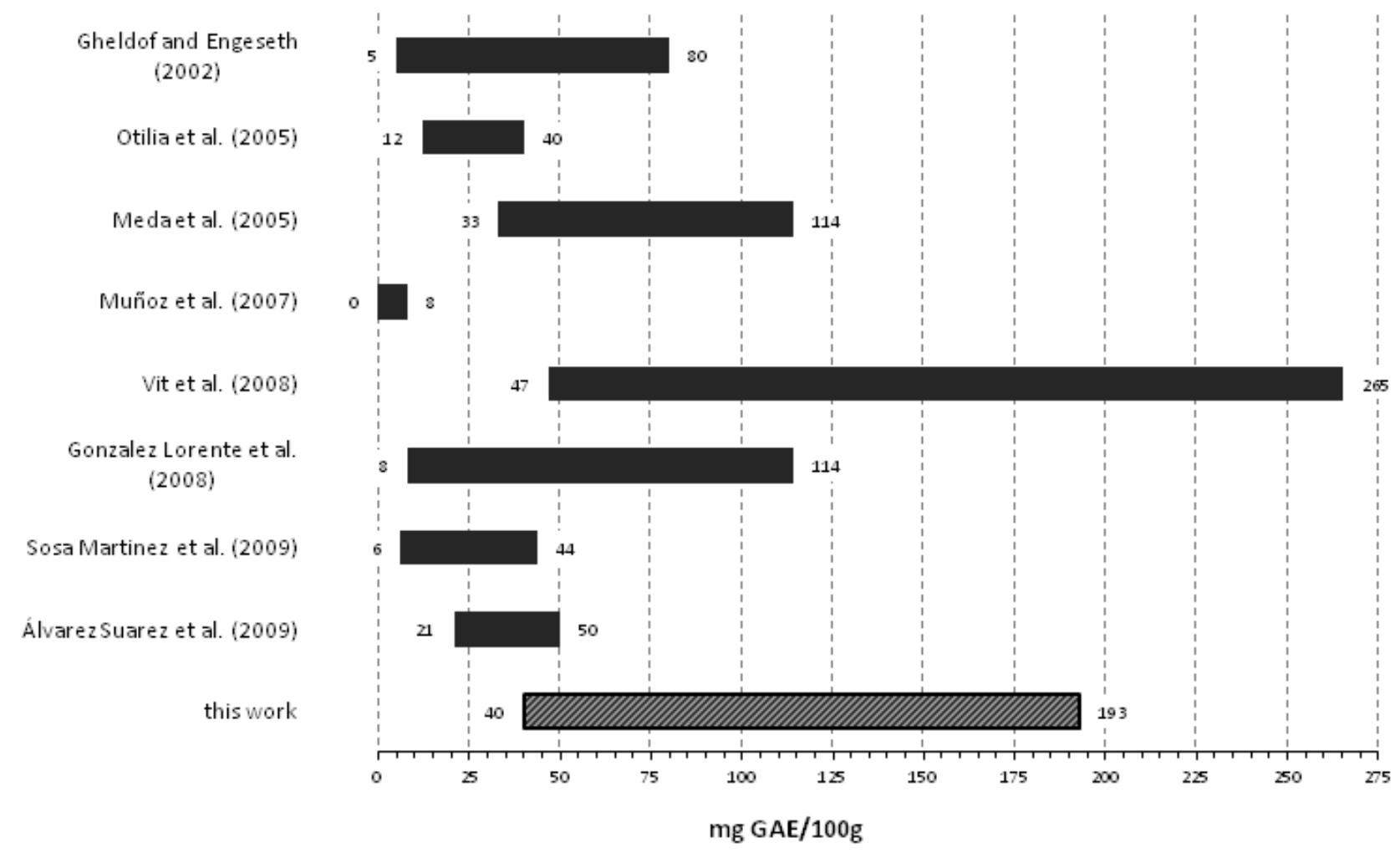

Fig. 3. Total soluble phenolic compound content in honey samples from different sources.

DDPH values were similar to those observed by González Lorente et al. (2008) and higher than those reported by Vela et al. (2007). In agreement with the results obtained in this work, published reports of TEAC showed contents ranging between 43.55 and 294.5 mg TE/100 g (Vit et al., 2008; Álvarez Suárez et al., 2009).

The range of $\mathrm{OH}$ values found in this study agrees with that published by Rodríguez et al. (2007). No background FRAC values were observed in honey, to establish a basis for comparison. Montenegro et al. (2013) determined the ferric-reducing ability of plasma (FRAP) in Chilean honey samples, which ranged from 0.1 to $0.59 \mathrm{mmol}$ Trolox equivalent $/ \mathrm{kg}$ honey.

When free radical-scavenging activity was analyzed, variables with more discrimination power were similar to the ones reported by lurlina et al. (2011) for honeys of Trifolium species, Melilotus species, Medicago sativa, and Lotus species. They were associated with higher phenolic compound content and with $\mathrm{OH}$ and DPPH radical capture capacities. Similar results had been reported in comparative research about fruits (Liu et al., 2008) and regarding pollen antioxidant activity from seven countries (Fuenmayor et al., 2011).

The lack of correlation between $\mathrm{OH}$ radical scavenging and the other scavenging assays might suggest that the mechanism of the $\mathrm{OH}$ capture reaction differs from the electron-transfer reactions or that this parameter is independent of the content of flavonoids and phenolic compounds. The correlations between total phenolic compounds, total flavonoid compounds, FRAC, and TEAC indicate that it would probably be unnecessary to perform all of these determinations.

Folin-Ciocalteu's method is largely used to evaluate total phenolic compounds. The determination of total soluble phenolic compounds is simple, and has the advantage that Folin-Ciocalteau's solution is stable and can be bought commercially, decreasing analytical errors. But the phosphowolframatephosphomolybdate complex also reacts with other non-phenolic reducing compounds, such as sugars and amino acids, leading to an overestimation of the phenolic content (Georgé et al., 2005). In fact, honey samples contain some of these compounds, as well as other antioxidants that can lead to an increase in the absorbance values and to positive errors in the determination of phenolic content when the Folin-Ciocalteu method is employed. Because the test does not accurately represent the total phenolic compound content, it would be appropriate to give it a different name (e.g., total antioxidant activity) (Prior et al., 2005). 


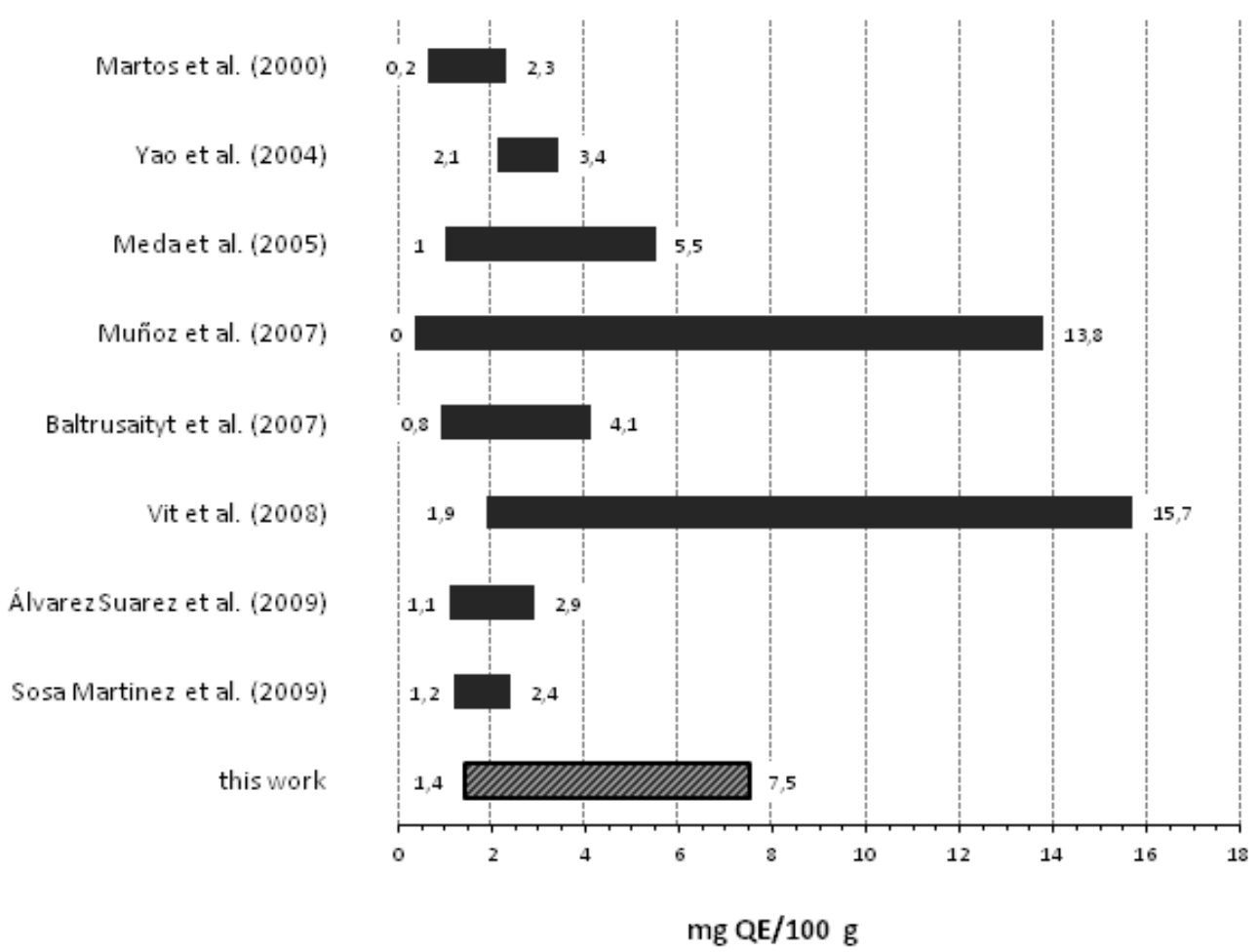

Fig. 4. Total flavonoid compound content in honey samples from different sources.

All honey samples exhibited antioxidant properties different from zero. Tea, red wine, and chocolate are foods with recognized antioxidant capacity. Among them, chocolate contains greater total phenolic compounds per portion than honey. While honey contains $18 \mathrm{mg}$ GAE per portion, chocolate contains up to $611 \mathrm{mg}$ GAE per portion. Black tea contains $124 \mathrm{mg} G A E$, green tea contains $165 \mathrm{mg}$ $\mathrm{GAE}$, and red wine contains $340 \mathrm{mg}$ GAE (Won Lee et al., 2003). The total phenolic compound content is also reportedly higher in red fruits (Vasco et al., 2008). However, the antioxidant capacity of honey was similar to the reported antioxidant capacity of tomatoes (Wu et al., 2004).

In addition to phenols and flavonoids, honey contains small amounts of proteins, enzymes, amino acids, minerals, trace elements, and vitamins. Thus, it is considered a food of nutritional interest. However, most of the properties of honey require an intake of between 50 and $80 \mathrm{~g}$ in order to have an effect (Bogdanov et al., 2008).

\section{CONCLUSION}

Results obtained in this study confirm that honey's composition depends to a great extent on its botanical origin. Thus, floral origin is also likely to influence most of honey's health-promoting properties.
It is necessary to reach a consensus regarding the most appropriate analytic method with which to determine the in vitro antioxidant capacity of honey. An interesting alternative would be to evaluate in vitro antioxidant capacity by determining the total phenolic compounds in a sample, in combination with an $\mathrm{OH}$ radical-scavenging activity assay.

\section{REFERENCES}

Aljadi A. M., Kamaruddin M. Y. (2004) Evaluation of the phenolic contents and antioxidant capacities of two Malaysian floral honeys. Food Chemistry 85: 513-518.

Arnao M. B., Cano A., Acosta M. (2001) The hydrophilic and lipophilic contribution to total antioxidant activity. Food Chemistry 73: 239-244.

Álvarez Suárez J. M., Tulipani S., Romandini S., Bompadre S., Vidal A., Battino S. (2009) Determinación de polifenoles y flavonoides totales en mieles uniflorales de Cuba y de su capacidad antioxidante total. In: Proceedings of III Congreso Cubano de Apicultura. La Habana - Cuba. 9-13 March 2009: 33.

Baltrušaitytè V., Venskutonis P. R., Čeksterytè V. (2007) Radical scavenging activity of different floral origin honey and beebread phenolic extracts. Food Chemistry 101: 502-514. DOl: 10.1016/j.foodchem.2006.02.007 
Beretta G., Granata P., Ferrero M., Orioli M., Facino R. M. (2005) Standardization of antioxidant properties of honey by a combination of spectrophotometric/fluorimetric assays and chemometrics. Analytica Chimica Acta 533: 185-191.

Bertonceij J., Dobersek U., Jamnik M., Golob T. (2007) Evaluation of the phenolic content, antioxidant activity and colour of Slovenian honey. Food Chemistry 105(2): 822-8.

Blasa M., Candiracci M., Accorsi A., Piacentini M. P., Piatti E. (2007) Honey flavonoids as protection agents against oxidative damage to human red blood cells. Food Chemistry 104: 1635-1640.

Bogdanov S., Jurendic T., Sieber R., Gallman P. (2008) Honey Nutrition and health: a review. Journal of the American College of Nutrition 27: 677-689.

Brand-Williams W., Cuvelier M. E., Berset C. (1995) Use of free radical method to evaluate antioxidant activity. Lebensmittel Food Science and Technology 28: 25-30.

Buratti S., Benedetti S., Cosio M. S. (2007) Evaluation of the antioxidant power of honey, propolis and royal jelly by amperometric flow injection analysis. Talanta 71: 1387-1392.

CODEX Stan 12 (2001) Codex Stan 12-1981. Adopted in 1981. Revisions 1987 and 2001. 17 pp. Available at: http://teca.fao.org/resource/codex-alimentarius-honeystandard

Fagúndez G. A., Caccavari M. A. (2006) Pollen analysis of honeys from the central zone of Argentine province of Entre Ríos. Grana 45: 305-320.

Fuenmayor C. A., Garcés L. D., Díaz-Moreno A., Quicazán M. C. (2011) A comparative study of the antioxidant activity of bee pollens from the world. In: Proceedings of $42^{\text {nd }}$ International Apicultural Congress of Apimondia. Buenos Aires - Argentina. 21-25 September 201 1:248.

Georgé S., Brat P., Alter P., Amiot M. (2005) Rapid determination of polyphenols and vitamina $C$ in plant-derived products. Journal of Agricultural And Food Chemistry 53: 1370-1373.

Gheldof H., Wang X., Engeseth N. J. (2002) Identification and quantification of antioxidant component of honeys from various floral sources. Journal of Agricultural and Food Chemistry 50(21): 5870-5877.
González Lorente M., De Lorenzo Carretero C., Pérez Martin R. A. (2008) Sensory attributes and antioxidant capacity of Spanish Honeys. Journal of Sensory Studies 23: 293-302.

Halliwell B., Gutteridge J., Aruoma O. (1987) The desoxyrribosa method: a simple test tube assay for determination of rate constants for reactions of hydroxyl radicals. Analytical Biochemistry 165: 215-219.

Hamdy A. A, Ismail H., AL- Ahwal A., Gomaa N. (2009) Determination of Flavonoids and Phenolic Acid Contents of Clover, Cotton and Citrus Floral Honeys. The Journal of the Egyptian Public Health Association 84(3\&4): $245-$ 259.

Iurlina M. O., Saiz I. A., Fangio F., Fritz R. (2011) Mieles monoflorales de trébol. Caracterización del potencial antioxidante, contenido de flavonoides y color. In: Proceedings of $42^{\text {nd }}$ International Apicultural Congress of Apimondia. Buenos Aires - Argentina. 21-25 Septembre $2011: 244$.

Johnson D. E. (2004) Métodos multivariados aplicados al análisis de datos. International Thomson Publishing. Madrid. 566 pp.

Kaškonienè V., Maruška A., Kornyšova O., Charczun N., Ligor M., Buszewski B. (2009) Quantitative and qualitative determination of phenolic compounds in honey. Chemical Technology 3(52): 74-80.

Liu X., Zhao M., Wang J., Yang B., Jiang Y. (2008) Antioxidant activity of methanolic extract of emblica fruit (Phyllanthus emblica L.) from six regions in China. Journal of Food Composition and Analysis 21 (3): 219-228.

Liviu M., Dezmirean D., Bobis O. (2011) Authenticity study of honey using specific markers for product traceability. In: Proceedings of $42^{\text {nd }}$ International Apicultural Congress of Apimondia. Buenos Aires - Argentina. 21-25 September $2011: 242$

Louveaux J., Maurizio A., Vorwohl G. (1978) Methods of Melissopalynology. Bee World 59: 139-157.

McKibben, J., Engeseth, N. J. (2002) Honey as a protective agent against lipid oxidation in ground turkey. Journal of Agricultural and Food Chemistry 50(3): 592-595.

Meda A., Lamien C. Romito M., Millongo J. Nacoulma 0. (2005) Determination of the total phenolic, flavonoids and proline contents in Burkina Fasan honey, as well as 
their radical scavening activity. Food Chemistry 91: 571 577.

Montenegro G., Santander F., Jara, C., Nuñez G., Fredes C. (2013) Actividad antioxidante y antimicrobiana de mieles monoflorales de plantas nativas chilenas. Boletín Latinoamericano y del Caribe de Plantas Medicinales y Aromáticas 12(3): 257-268.

Muñoz O., Copaja S., Speisky H., Peña R., Montenegro G. (2007) Contenido de flavonoides y compuestos fenólicos de mieles chilenas e índice antioxidante. Quimica Nova 30(4): 848-851.

Otilia B., Socaciu C., Mărghitas L., Dezmirean D. (2005) Correlations between total phenols, flavonoids, colour intensity and botanical origin of some honeys from Transilvania region. Bulletin of the University of Agricultural Science and Veterinary Medicine 61: 349-353..

Oyaizu M. (1986) Studies on the products of browning reaction prepared from glucosamine. Japan Journal of Nutrition 44: 307-315.

Pérez R. A., Iglesias M. T., Pueyo E., González M., de Lorenzo C. (2007) Amino acid composition and antioxidant capacity of Spanish honeys. Journal of Agricultural Food Chemistry 55(2): 360-365.

Prior R. L., Wu X. L., Schaich K. (2005) Standardized methods for the determination of antioxidant capacity and phenolics in foods and dietary supplements. Journal of Agricultural and Food Chemistry 53(10): 4290-4302.

Rodríguez A., Pérez E., Vit P. (2007) Capacidad antioxidante de mieles venezolanas de los géneros Apis, Melipona y Tetragonisca, evaluados por tres métodos. Revista del Instituto Nacional de Higiene Rafael Rangel 38(2): 30-34.

Roginsky V., Lissi E. (2005) Review of methods to determine chain-breaking antioxidant activity in food. Food Chemistry 92: 235-254.

SAS Institute (2011) SAS/OR 9.3 User's Guide: Mathematical Programming. SAS Institute, Cary. USA.
Singleton V. L., Orthofer R., Lamuela Raventos R. M. (1999) Analysis of total phenol and other oxidation substrates and antioxidants by means of Folin-Ciocalteau reagent. Methods Enzymology 299: 152-178.

Sosa Martínez R., Tenori Borroto E., Marrero Chang O., Águila Gímenez E., Camacho Bordón S., Morales Montero A. (2009) Determinación de compuestos fenólicos, metales y su efecto sobre el potencial antioxidante y tóxico en mieles procedentes de Apis mellifera. In: Proceedings of III Congreso Cubano de Apicultura. La Habana, Cuba. 9-13 March 2009: 154.

Vasco C., Ruales J., Kamal Eldin A. (2008) Total phenolic compounds and antioxidant capacities of major fruits from Ecuador. Food Chemistry 1 11:816-823.

Vela L., de Lorenzo C., Pérez, R. A. (2007) Antioxidant capacity of Spanish honeys and its correlation with some physicochemical parameters and poliphenolic content. Journal of the Science of Food and Agriculture 87: 1069 1075 .

Vit P., Gutiérrez M. G., Titera D., Vendar M., Rodríguez Malaver A. J. (2008) Mieles checas categorizadas según su actividad antioxidante. Acta de Bioquímica Clínica Latinoamericana 42(2): 237-244.

Woisky R., Salatino A. (1998) Analysis of propolis: some parameters and procedures for chemical quality control. Journal of Apicultural Research 37: 99-105.

Won Lee K., Jun Kim Y., Joo Lee H., Yong Lee C. (2003) Cocoa has more phenolic phytochemicals and higher antioxidant capacity than teas and red wine. Journal of Agricultural and Food Chemistry 41: 792-795.

Wu X., Beecher G. R., Holden J. M., Haytowitz D. B., Gebardt E. S., Prior R. L. (2004) Lypophilic and hydrophilic antioxidant capacity of common foods in the United States. Journal of Agricultural and Food Chemistry 52: 4026-4037. 